\title{
Inter-island Movements of Two Barbary Falcon (Falco peregrinus pelegrinoides) Juveniles in the Canary Islands
}

Authors: Rodríguez, Beneharo, Bécares, Juan, Lorenzo, Juan Antonio, and Rodríguez, Airam

Source: Journal of Raptor Research, 52(4) : 503-510

Published By: Raptor Research Foundation

URL: https://doi.org/10.3356/JRR-18-16.1

BioOne Complete (complete.BioOne.org) is a full-text database of 200 subscribed and open-access titles in the biological, ecological, and environmental sciences published by nonprofit societies, associations, museums, institutions, and presses.

Your use of this PDF, the BioOne Complete website, and all posted and associated content indicates your acceptance of BioOne's Terms of Use, available at www.bioone.org/terms-of-use.

Usage of BioOne Complete content is strictly limited to personal, educational, and non - commercial use. Commercial inquiries or rights and permissions requests should be directed to the individual publisher as copyright holder.

BioOne sees sustainable scholarly publishing as an inherently collaborative enterprise connecting authors, nonprofit publishers, academic institutions, research libraries, and research funders in the common goal of maximizing access to critical research. 


\title{
Short Communications
}

J. Raptor Res. 52(4):503-510

(C) 2018 The Raptor Research Foundation, Inc.

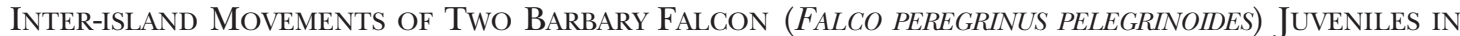 THE CANARY ISLANDS}

\author{
BENEHARO RODRÍGUEZ ${ }^{1}$ \\ Canary Islands' Ornithology and Natural History Group (GOHNIC), C/La Malecita S/N, 38480 Buenavista del Norte, \\ $S / C$ de Tenerife, Canary Islands, Spain \\ and
}

SEO/BirdLife, Delegación de Canarias, C/ Heraclio Sánchez, 21, 38204, La Laguna, S/C de Tenerife, Canary Islands, Spain

\author{
JuAn BÉCARes AND JuAn ANTONio LoREnZo
}

SEO/BirdLife, Delegación de Canarias, C/ Heraclio Sánchez, 21, 38204, La Laguna, S/C de Tenerife, Canary Islands, Spain

\author{
AIRAM RODRÍGUEZ \\ Canary Islands' Ornithology and Natural History Group (GOHNIC), C/La Malecita S/N, 38480 Buenavista del Norte, \\ $S / C$ de Tenerife, Canary Islands, Spain \\ and \\ Department of Evolutionary Ecology, Estación Biológica de Doñana (CSIC), Avda. Américo Vespucio 26, \\ 41092 Seville, Spain
}

\begin{abstract}
We studied the post-fledging movement of two sibling (male and female) juvenile Barbary Falcons (Falco peregrinus pelegrinoides) hatched in Lanzarote (Canary Islands) in 2011 using satellite tracking. Birds were tracked from fledging in May to the end of November, when the signals of both transmitters were lost. During the first $45 \mathrm{~d}$ following fledging, both birds behaved similarly and made some flights $<70$ $\mathrm{km}$ away from their nest, on the island where they hatched. However, after the dependence period, we found differences between the individuals. The female made several inter-island movements among the islands of the central archipelago (Gran Canaria, Tenerife and La Gomera) and returned to Lanzarote in October. In contrast, the male stayed close to his natal nest $(<100 \mathrm{~km})$ until the end of October, when he was detected in the middle of the Atlantic Ocean $>3000 \mathrm{~km}$ from the nest, probably using a ship as a perch. Because Barbary Falcon populations of the Canary Islands are listed as "threatened" due to anthropogenic threats (e.g. collisions with human-made structures, illegal shooting, nest-robbing, and hybridization with escaped falconry falcons) and little is known about their post-fledging dispersal movements, more studies of such life-history characteristics, using ringing and remote sensing, are urgently needed to develop management actions for their conservation.
\end{abstract}

Key Words: Barbary Falcon; Peregrine Falcon; Falco peregrinus pelegrinoides; Canary Islands; dispersal; endangered species; juvenile, remote sensing.

\section{MOVIMIENTOS ENTRE ISLAS DE DOS JUVENILES DE FALCO PEREGRINUS PELEGRINOIDES EN LAS ISLAS CANARIAS}

RESUMEN.-Estudiamos el movimiento post-emplumamiento de dos juveniles hermanos (macho y hembra) de Falco peregrinus pelegrinoides que nacieron en Lanzarote (Islas Canarias) en 2011, usando telemetría satelital. Las aves fueron seguidas desde el emplumamiento en mayo hasta fines de noviembre, cuando se perdió la señal de ambos transmisores. Durante los primeros 45 días tras el emplumamiento, ambas aves se

\footnotetext{
${ }^{1}$ Email address: benerguez@gmail.com
} 
comportaron de modo similar y realizaron algunos vuelos de $<70 \mathrm{~km}$ desde sus nidos, adentro de la isla en donde nacieron. Sin embargo, tras el período de dependencia, encontramos diferencias entre los individuos. La hembra realizó varios movimientos entre las islas del archipiélago central (Gran Canaria, Tenerife y La Gomera) y regresó a Lanzarote en octubre. Por el contrario, el macho permaneció cerca de su nido de nacimiento $(<100 \mathrm{~km})$ hasta fines de octubre, cuando fue detectado en medio del Océano Atlántico a $>3000 \mathrm{~km}$ del nido, probablemente usando un barco como posadero de caza. Debido a que las poblaciones de F. p. pelegrinoides de las Islas Canarias están catalogadas como "amenazadas" por causa de amenazas antropogénicas (e.g. colisiones con estructuras antrópicas, caza ilegal, robo de nidos e hibridación con halcones de cetrería), y a que se sabe poco sobre sus movimientos de dispersión postemplumamiento, se necesitan con urgencia más estudios sobre estas características de la historia de vida, usando anillamiento y teledetección, para desarrollar acciones de manejo para su conservación.

\section{[Traducción del equipo editorial]}

Post-fledging behavior and movements have important implications for spatial population structure, survival, and gene flow within raptor populations (Bullock et al. 2002). Three distinct phases during juveniles' first years of life can be distinguished, namely, the dependence period, the departure from the parental territory, and the settlement in areas of first breeding (Wiens et al. 2006, Cadahía et al. 2010). For long-lived raptor species, the first several months after fledging are critical for its survival and the time elapsed between departure from the natal site and settlement in the area of first breeding may be several years (Newton 1979). Therefore, gathering precise speciesspecific information on these phases is important for developing management and conservation measures such as the designation of protected areas (Prugnolle et al. 2003, Balbontín and Ferrer 2009, Dzialak et al. 2009, Yamaç and Bilgin 2012, Balotari-Chiebao et al. 2016).

The Peregrine Falcon (Falco peregrinus) is one of the most well-known and well-studied birds of the world (Cade et al. 1988, Ratcliffe 1993, Sielicki and Mizera 2009, White et al. 2013). A total of 18 recognized subspecies occurs in the world; northern populations are generally migratory, while southern and insular populations tend to be sedentary (White et al. 2013). Most published data regarding movements and dispersal patterns of juvenile Peregrine Falcons describe patterns of continental populations of North America or Europe. Furthermore, the majority of such studies are based on direct observations or ring recoveries (Sherrod 1983, Mearns and Newton 1984, Powell et al. 2002, Dzialak et al. 2005, 2009, Zuberogoitia et al. 2009, Dennhardt and Wakamiya 2013, Faccio et al. 2013). Following fledging, the Peregrine Falcon juveniles depend on their parents for a period of time, developing flight and hunting abilities. After that, young disperse from their natal site until they settle in a breeding territory (Sherrod 1983, Monneret 2000).

The Barbary Falcon (F. p. pelegrinoides), considered by some authors an independent species, inhabits areas from northwestern Africa (including the Canary Islands, the westernmost portion of the breeding range) to the Middle East; furthermore, Barbary Falcon populations are considered sedentary or nonmigratory (Ferguson-Lees and
Christie 2001, Rodríguez et al. 2009, White et al. 2013). In the Canary Islands, Barbary Falcon numbers have increased over the last two decades, from seven territories in 1990 to 180 in 2017, and such increases have been attributed to concomitant legal protection and increased prey availability (Rodríguez et al. 2009, Siverio et al. 2009, B. Rodríguez unpubl. data). However, these falcons still face several threats to their survival and reproduction, including collisions with human-made structures, illegal shooting, nest-robbing, and hybridization with escaped falconry falcons (Rodríguez et al. 2009, 2010). Such issues have culminated in the Barbary Falcon being listed as "Endangered" in the Spanish National and Regional catalogs of threatened species (Siverio and Concepción 2004).

Although some aspects of the Barbary Falcon breeding biology and habitat selection have been studied in the Canaries (Delgado et al. 1999, Rodríguez and Siverio 2006, Rodríguez et al. 2007, Siverio et al. 2011), specific studies on its ecology are scarce in the entire breeding range, and little is known about post-fledging movements (Rodríguez et al. 2009, White et al. 2013). Here, we describe the postfledging movements of two Canarian Barbary Falcon juveniles using satellite tracking (Meyburg and Fuller 2007). The main goals of this preliminary study were (1) to investigate the range used by juvenile falcons as they disperse from their natal area, and (2) to determine the use of other nearby islands as dispersal sites. We also discuss the implications for the conservation of this endangered raptor.

\section{MeTHODS}

Study Area and Species. The Canary Islands are a volcanic archipelago located about $100 \mathrm{~km}$ off the Atlantic coast of northwest Africa $\left(27^{\circ} 37^{\prime}-29^{\circ} 25^{\prime} \mathrm{N}\right.$ and $13^{\circ} 20^{\prime}-$ $18^{\circ} 19^{\prime} \mathrm{W}$ ) that comprises seven major islands. Lanzarote Island, located in the northeast of the Canarian archipelago (Fig. 1, 2), is dominated by a flat landscape and barren volcanic ground. The breeding population of Barbary Falcon on Lanzarote is resident and currently numbers approximately 20 breeding pairs, which nest on high cliffs 


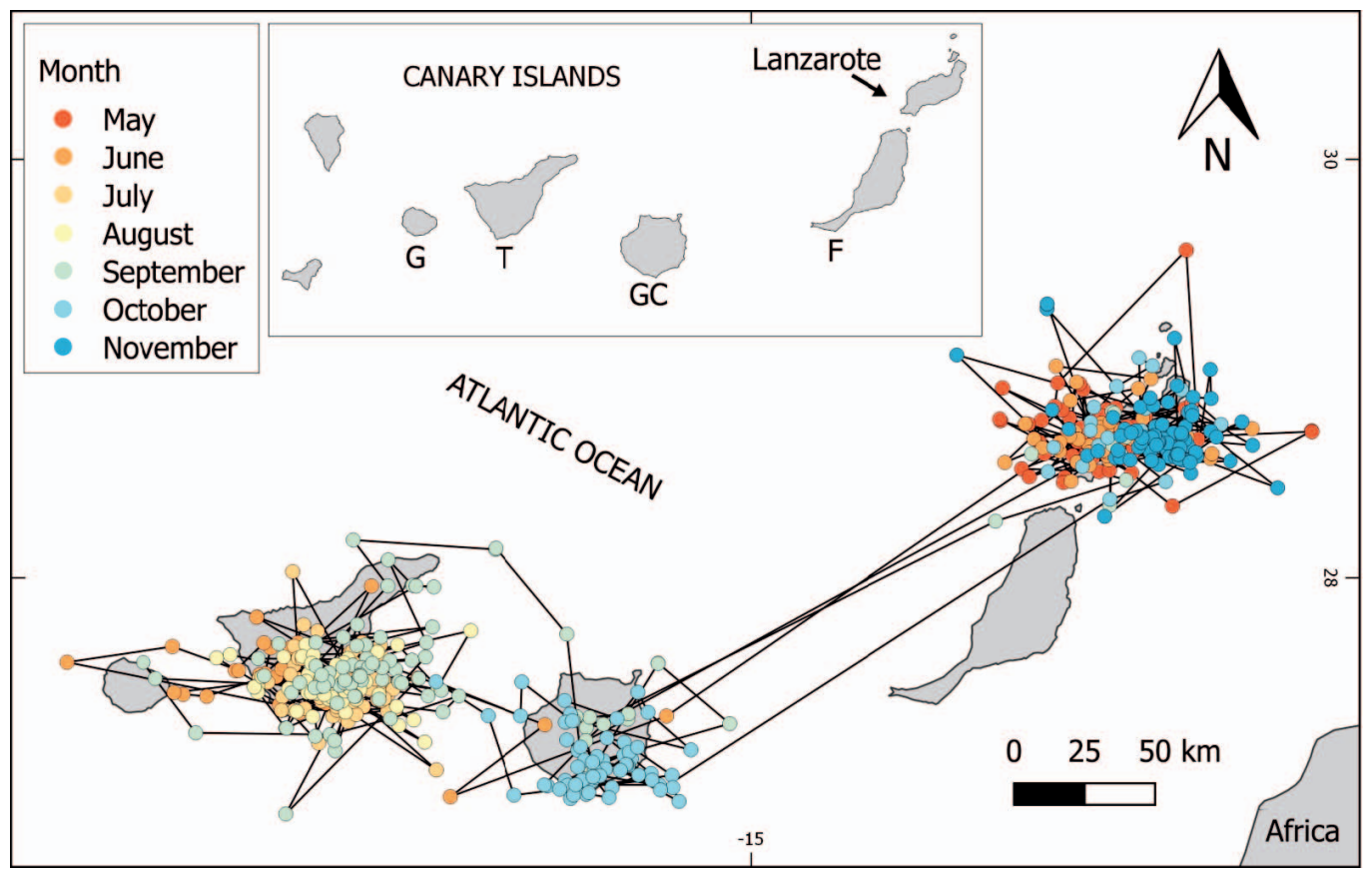

Figure 1. Dispersal of a female (PTT-71835) Barbary Falcon (Falco peregrinus pelegrinoides) that fledged from Timanfaya National Park, Lanzarote, Canary Islands (see location details in Table 1; G = La Gomera; $\mathrm{T}=$ Tenerife; GC $=$ Gran Canaria; F = Fuerteventura).

when they are available (Rodríguez et al. 2009, Siverio et al. 2009). They feed mainly on feral Rock Pigeons (Columba livia), but also prey on other small to medium-sized resident and migratory birds (Rodríguez et al. 2009).

Satellite Tracking. On 29 April 2011, we deployed two 12-g solar-powered PTTs (Microwave Telemetry, Inc., Columbia, MD, USA) on two 25-30-d-old sibling nestlings (from a brood of three). Their natal eyrie was located on a rock face on a small crater in Timanfaya National Park (Lanzarote). We used climbing equipment to reach the nest and capture the nestlings. The sexual size dimorphism of Barbary Falcons allowed us to visually sex the birds (White et al. 2013; Table 1). We used backpack harnesses made of Teflon ribbon to attach the PTTs. The PTTs weighed $<3 \%$ of the body mass of the tagged birds (Table 1 ), and were programmed to transmit for $12 \mathrm{hr}$ and turn off for a 48-hr recharging period. Both devices stopped recording data during November 2011 for unknown reasons (Table 1).

Data Processing and Analysis. Locations of falcons were downloaded from the ARGOS website (http://www. argos-system), which provides locations with an associated estimate of accuracy (location class, LC) based on the quality of the signal. Location class is divided into seven categories (in descending order of accuracy 3, 2, 1, 0, A, B, $\mathrm{Z}$ ). Argos suggests estimated accuracies of $<150,150-350$, 350-1000 and $>1000 \mathrm{~m}$ for LC 3, 2, 1, and 0, respectively
(Meyburg and Fuller 2007). For A and B location class categories there are no estimates of location accuracy. We did not obtain locations of class 3 and 2, suggesting some interference with the frequency used by ARGOS satellites, which has been noted in the Mediterranean basin, rather than a malfunctioning of the devices (Soutullo et al. 2007). All locations, except class $\mathrm{Z}$, were filtered to remove incorrect or impossible positions (such as those suggesting travel speeds of $>125 \mathrm{~km} / \mathrm{hr}$, see Enderson and Craig $1997)$; this process retained up to $85 \%$ of the original locations (see Table 1). We calculated the distance from each location to the nest using QGIS version 2.18 (Open Source Geospatial Foundation Project, http:/ qgis.osgeo. org), and classified the locations as occurring during the dependence period (May and June, Sherrod 1983), or the dispersal period (after June). We used $U$-tests for independent samples to compare mean distances (from bird locations to the nest) between siblings during the dependence phase (May-mid-June).

\section{Results AND Discussion}

After filtering, we retained a total of 1213 usable locations for both juveniles from May to November 2011 (Table 1). During the dependence phase, both falcons made short movements, and distances from the nest were 

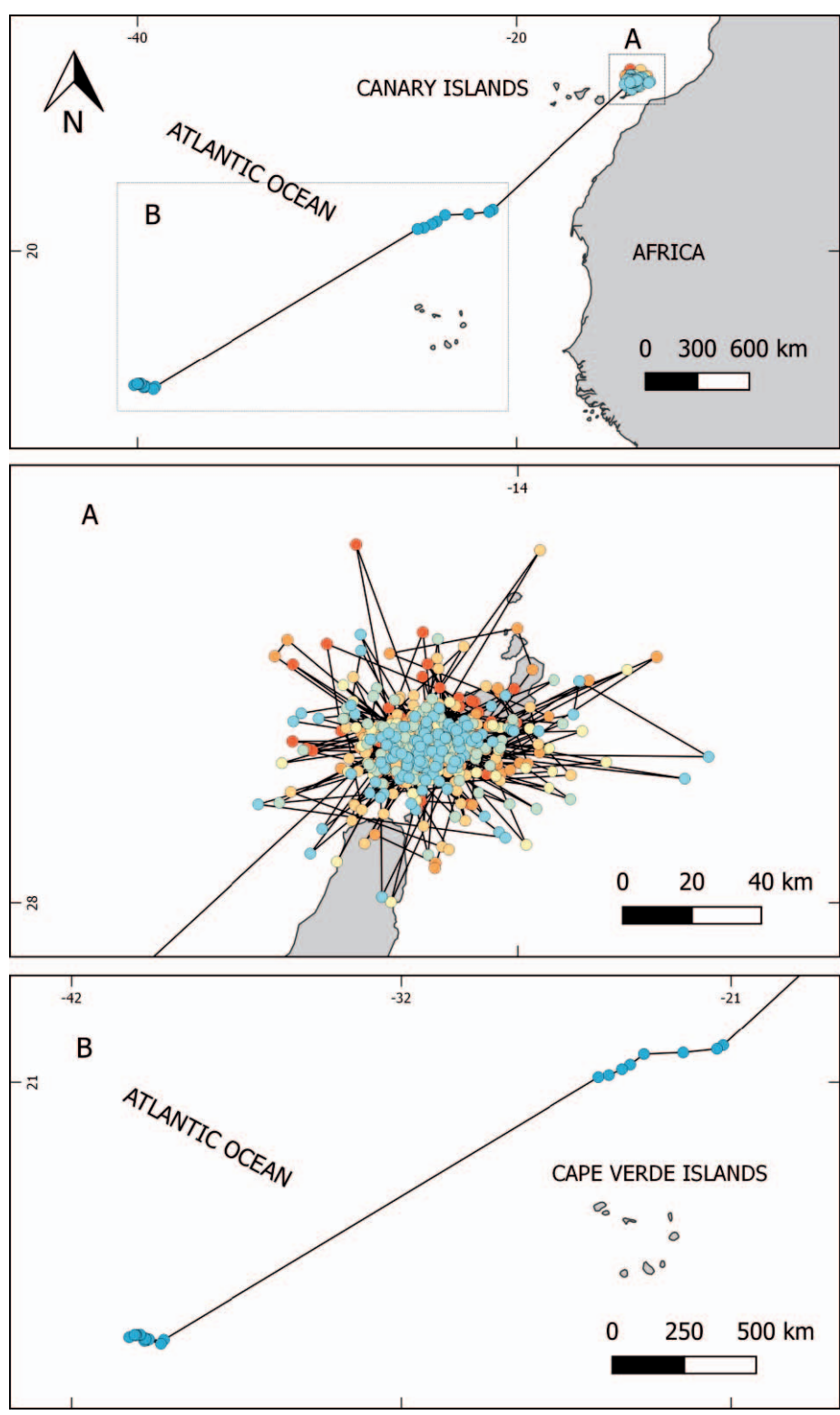

Figure 2. Dispersal of a male (PTT-71902) Barbary Falcon (Falco peregrinus pelegrinoides) that fledged from Timanfaya National Park, Lanzarote, Canary Islands (see location details in Table 1; see Fig. 1 for legend).

similar for both birds (mean $\pm \mathrm{SD}$ for female $=16.4 \pm 14.4$ $\mathrm{km}[n=134]$ and for male $=14.7 \pm 12.6 \mathrm{~km}[n=120] ; U=$ $8737, P=0.154$; Fig. 3). During this time, the juveniles were likely provisioned by their parents and thus remained on Lanzarote, although they presumably also learned to hunt prior to dispersing from the natal site (Sherrod 1983, Fig. 1-3). Both birds flew up to $70 \mathrm{~km}$ from their nest during this phase (Fig. 3). The boundaries of the island may have limited their initial flights during this dependence period, as the distance they traveled from the nest was much less than the $>300 \mathrm{~km}$ reached by some male juvenile Peregrine Falcons in continental areas during the first month after fledging (Zuberogoitia et al. 2009).

During the dispersal phase, the two birds behaved differently. The female made several inter-island movements, visiting Gran Canaria, Tenerife, and La Gomera 
Table 1. Tracking period and number of locations retained after filtering (see details in the main text) for two Barbary Falcon (Falco peregrinus pelegrinoides) juveniles PTT-tagged in 2011 on Lanzarote, Canary Islands.

\begin{tabular}{|c|c|c|c|c|c|c|c|c|c|}
\hline \multirow[b]{2}{*}{ BIRD } & \multirow[b]{2}{*}{ PTT } & \multirow[b]{2}{*}{ Mass } & \multirow[b]{2}{*}{ Tracking Period 2011} & \multirow{2}{*}{$\begin{array}{l}\text { NuMBER OF DAYS } \\
\text { WITH LOCATIONS }\end{array}$} & \multicolumn{5}{|c|}{ Number OF LOCATIONS (LC) } \\
\hline & & & & & 0 & 1 & A & B & TOTAL \\
\hline Female & 71835 & $920 \mathrm{~g}$ & 2 May-20 November & 103 & 386 & 14 & 64 & 121 & 585 \\
\hline Male & 71902 & $600 \mathrm{~g}$ & 2 May-6 November & 94 & 435 & 9 & 64 & 120 & 628 \\
\hline
\end{tabular}

(Table 2, Fig. 1). In contrast, the male made approximately nine short excursions to the north of Fuerteventura; during the first fortnight of July he moved to the southern portion of Lanzarote and remained on the island until the end of October; on 30 October he was detected on the Atlantic Ocean, and on the first $6 \mathrm{~d}$ of November, transmitter signals indicated that he was $>3000 \mathrm{~km}$ from Lanzarote in the middle of the Atlantic Ocean (Fig. 2). We do not know why he traveled so far from the Canary Islands; however, we cannot rule out that

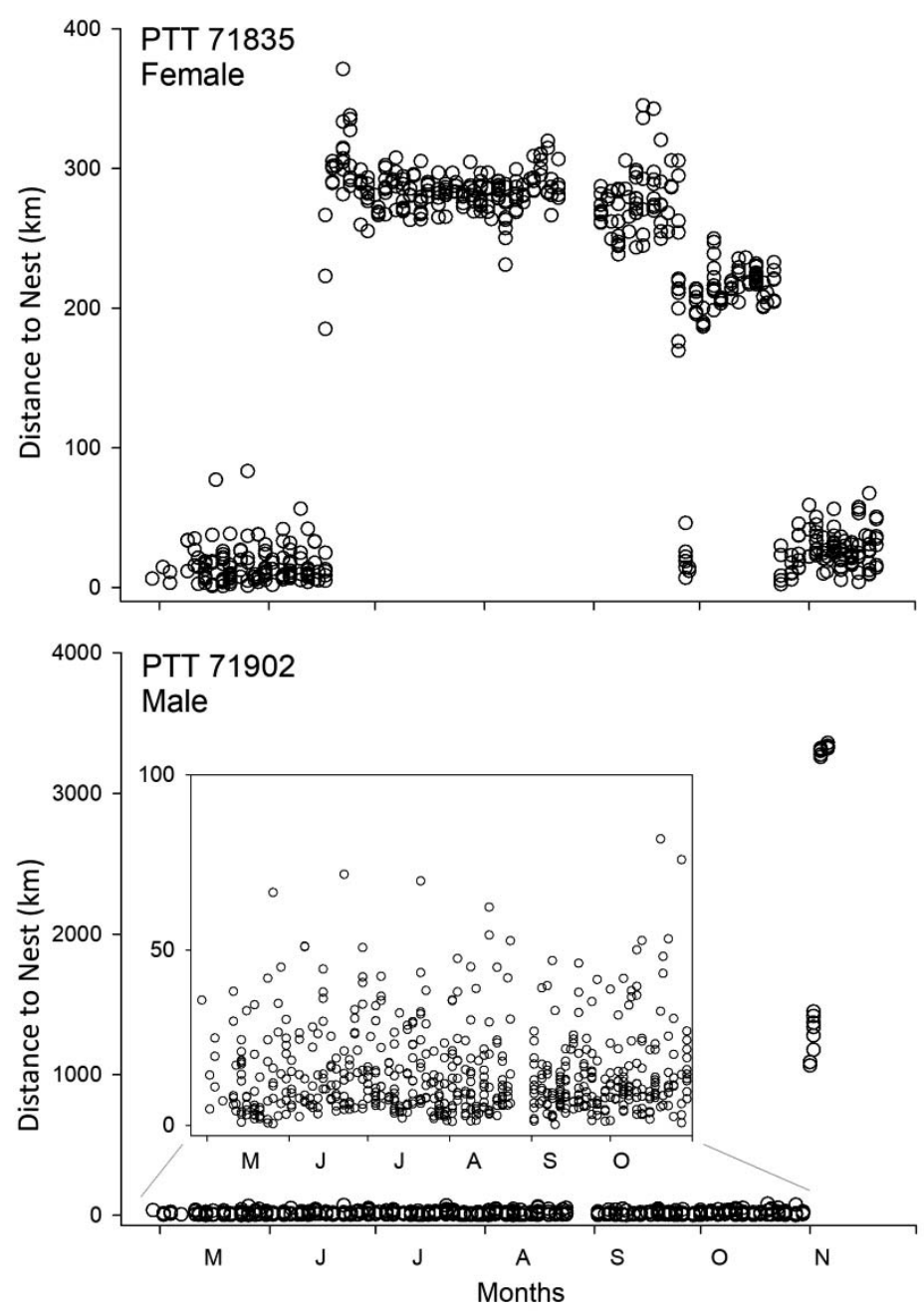

Figure 3. Distances to the natal nest of Barbary Falcon (Falco peregrinus pelegrinoides) juveniles fledged from Timanfaya National Park, Lanzarote, Canary Islands: top: female PTT 71835; bottom: male PTT 71902. 
Table 2. Summary of inter-island movement of the female Barbary Falcon (Falco peregrinus pelegrinoides) juvenile PTT-tagged from May to November 2011.

\begin{tabular}{ll}
\hline \multicolumn{1}{c}{ Date } & \multicolumn{1}{c}{ Movement Activities } \\
\hline 2 May & Tagged with PTT at nest on Lanzarote \\
17 June & Flew from Lanzarote to Gran Canaria \\
19 June & Flew from Gran Canaria to Tenerife \\
22 June & Flew to La Gomera and returned to \\
& Tenerife \\
15 September & Flew to La Gomera \\
19 September & Was on Tenerife \\
25 September & Flew from Tenerife to Gran Canaria \\
28 September & Flew from Gran Canaria to Lanzarote \\
30 September & Flew to Gran Canaria \\
19 October & Flew to Lanzarote \\
20 November & PTT lost signal \\
\hline
\end{tabular}

he used a vessel as a perch (see Whittington 2014, Stabile et al. 2016).

During their first long-distance dispersal flights, both birds flew toward the southwest (Fig. 1,2). It is possible that the prevailing Canary Islands winds, dominated by humid trade winds from the northeast (Barton et al. 1998, Calero and Carta 2004), influenced their dispersal direction. Previous work suggests an age-dependent difference in the ability to compensate for wind drift among migratory raptors, a potential challenge for juvenile birds (Thorup et al. 2003). Another possible influence that we cannot rule out is that juvenile falcons can see the summits of the western islands (with peaks higher than 1500 masl) from Lanzarote but not the low-altitude coast of West Africa, and this may serve as a visual stimulus for movement.

Female juvenile Peregrine Falcons typically disperse farther than males (Mearns and Newton 1984, Zuberogoitia et al. 2009, Dennhardt and Wakamiya 2013). The wandering behavior of the female we tracked across the archipelago and to several islands agrees with the general pattern of sex-specific differences in dispersal. Although we could not determine recruitment in our study, the ability of the two young falcons to reach other islands suggests juvenile Barbary Falcons may settle on islands other than their natal one. As a result, the Canarian archipelago may host a metapopulation of Barbary Falcons. This underscores the need for organization among insular governments to undertake inter-regional conservation measures targeting the nonbreeding fraction of Barbary Falcons.

Because of the small sample size sometimes associated with satellite tracking, an intensive monitoring program (using ringing together with remote tracking) in the entire archipelago could help elucidate the population ecology of the Barbary Falcon. For example, we do not know why the proportion of breeding falcons expressing the "Barbary" phenotype seems to be declining in favor of the typical peregrine type, resulting in a mixture of phenotypes
(Rodríguez et al. 2011, B. Rodríguez unpubl. data). There are two non-mutually exclusive possible explanations of the origin of these "typical peregrine" individuals: a natural colonization from the nearby mainland wild populations of Peregrine Falcon (F. p. brookei), or hybridization with escaped falconry birds (B. Rodríguez unpubl. data). A better understanding of dispersion ecology of Canarian and North African falcon populations will help managers develop appropriate conservation strategies.

Given the recovery of the species during the last $30 \mathrm{yr}$ expanding from the eastern islands (Lanzarote and Fuerteventura) to the rest of the archipelago, researchers suspected inter-island movements might explain such population increase (Rodríguez et al. 2009). The satellite tracking technology employed in our preliminary study has revealed multiple inter-island movements of juvenile Barbary Falcons before recruitment into a breeding population, suggesting that Canarian Barbary Falcons are a meta-population in which falcons hatched on one island might eventually breed on another. Because gathering information on the foraging and dispersal areas of juvenile falcons is important for identifying potential threats, such as collisions with human-made infrastructures, persecution, or poisoning, our preliminary study should help inform the design of future research.

\section{ACKNOWLEDGMENTS}

We thank the rangers of the Timanfaya National Park: Jorge Espinel, Luz Mejías, Urbano Hernández, and Juan Morales for their help during the fieldwork. We are indebted to Victor García Matarranz (Ministerio de Medio Ambiente, y Rural y Marino) and Rafael Riera (GESPLAN) for their help in the capture, tagging, and ringing. Two anonymous reviewers and the editors greatly improved an earlier version of this report. The Wildlife Rehabilitation Center of La Tahonilla permitted us to measure some admitted and unreleasable Barbary Falcons to design suitable harnesses. This work was conducted by SEO/ BirdLife but funded by the Timanfaya National Park (Gobierno de Canarias) through GESPLAN. AR was supported by the Spanish Ministry of Economy, Industry and Competitiveness (Juan de la Cierva-Incorporación, IJCI-2015-23913). Thanks to the local government (Viceconsejería de Medio Ambiente-Gobierno de Canarias) for granting official permit No 637, issued on 9 November 2010 .

\section{Literature Cited}

Balbontín, J., and M. Ferrer (2009). Movements of juvenile Bonelli's Eagles Aquila fasciata during dispersal. Bird Study 56:86-95.

Balotari-Chiebao, F., A. Villers, A. Ijäs, O. Ovaskainen, S. Repka, and T. Laaksonen (2016). Post-fledging movements of White-tailed Eagles: conservation implications for wind-energy development. Ambio 45:831-840. 
Barton, E. D., J. Arístegui, P. Tett, M. Cantón, J. GarcíaBraun, S. Hernández-León, L. Nykjaer, C. Almeida, J. Almunia, S. Ballesteros, G. Basterretxea, et al. (1998). The transition zone of the Canary Current upwelling region. Progress in Oceanography 41:455-504.

Bullock, J. M., R. E. Kenward, and R. S. Hails (2002). Dispersal Ecology. Blackwell, Oxford, UK.

Cadahía, L., P. López-López, and V. Urios (2010). Satellite telemetry reveals individual variation in juvenile Bonelli's Eagle dispersal areas. European Journal of Wildlife Research 56:923-930.

Cade, T., J. Enderson, C. Thelander, and C. M. White (Editors) (1988). Peregrine Falcon Populations: Their Management and Recovery. The Peregrine Fund, Boise, ID, USA.

Calero, R., and J. A. Carta (2004). Action plan for wind energy development in the Canary Islands. Energy Policy 32:1185-1197.

Delgado, G., D. Concepción, M. Siverio, E. Hernández, V. Quilis, and D. Trujillo (1999). Datos sobre la distribución y biología del halcón de berbería (Falco peregrinus pelegrinoides) en las Islas Canarias (Aves: Falconidae). Vieraea 27:287-298.

Dennhardt, A., and S. Wakamiya (2013). Effective dispersal of Peregrine Falcons (Falco peregrinus) in the Midwest, USA. Journal of Raptor Research 47:262-270.

Dzialak, M. R., K. M. Carter, M. J. Lacki, D. F. Westneat, and K. Ersen (2009). Activity of post-fledging Peregrine Falcons in different rearing and habitat conditions. Southeastern Naturalist 8:93-106.

Dzialak, M. R., M. J. Lacki, J. L. Larkin, K. M. Carter, and S. Vorisek (2005). Corridors affect dispersal initiation in reintroduced Peregrine Falcons. Animal Conservation 8:421-430.

Enderson, J. H., and G. R. Craig (1997). Wide ranging by nesting Peregrine Falcons (Falco peregrinus) determined by radiotelemetry. Journal of Raptor Research 31:333338.

Faccio, S., M. Amaral, C. Martin, J. Lloyd, T. French, and A. Tur (2013). Movement patterns, natal dispersal, and survival of Peregrine Falcons banded in New England. Journal of Raptor Research 47:246-261.

Ferguson-Lees, J., and D. A. Christie (2001). Raptors of the World. Christopher Helm, London, UK.

Mearns, R., and I. Newton (1984). Turnover and dispersal in a peregrine Falco peregrinus population. Ibis 126:347355 .

Meyburg, B.-U., and M. R. Fuller (2007). Satellite tracking. In Raptor Research and Management Techniques (D. M. Bird and K. L. Bildstein, Editors). Hancock House Publishers, Surrey, BC, Canada. pp. 242-248.

Monneret, R.-J. (2000). Le Faucon Pèlerin. Delachaux et Niestlé, Paris, France.

Newton, I. (1979). Population Ecology of Raptors. T. and A. D. Poyser, Berkhamsted, UK.
Powell, L. A., D. Calvert, I. M. Barry, and L. Washburn (2002). Post-fledging survival and dispersal of Peregrine Falcons during a restoration project. Journal of Raptor Research 36:176-182.

Prugnolle, F., P. Pilard, L. Brun, and G. Tavecchia (2003). First-year and adult survival of the endangered Lesser Kestrel Falco naumanni in southern France. Bird Study 50:68-72.

Ratcliffe, D. A. (1993). The Peregrine Falcon. T. and A. D. Poyser, Calton, UK.

Rodríguez, B., A. Rodríguez, F. Siverio, and M. Siverio (2010). Causes of raptor admissions to a wildlife rehabilitation center in Tenerife (Canary Islands). Journal of Raptor Research 44:30-39.

Rodríguez, B., F. Siverio, M. Siverio, and A. Rodríguez (2011). Variable plumage coloration of breeding Barbary Falcons Falco (peregrinus) pelegrinoides in the Canary Islands: do other Peregrine Falcon subspecies also occur in the archipelago? Bulletin of the British Ornithological Club 131:140-153.

Rodríguez, B., F. Siverio, M. Siverio, A. Rodríguez, and J. J. Hernández (2009). Pasado y presente del halcón de berbería en las Islas Canarias. El Indiferente 20:12-21.

Rodríguez, B., and M. Siverio (2006). Density and breeding habitat characteristics of an insular population of Barbary Falcon Falco peregrinus pelegrinoides (El Hierro, Canary Islands). Ardeola 53:325-331.

Rodríguez, B., M. Siverio, A. Rodríguez, and F. Siverio (2007). Density, habitat selection and breeding success of an insular population of Barbary Falcon Falco peregrinus pelegrinoides. Ardea 95:213-223.

Sherrod, S. (1983). Behavior of Fledgling Peregrines. The Peregrine Fund, Ithaca, New York, NY, USA.

Sielicki, J., and T. Mizera (Editors) (2009). Peregrine Falcon Populations-Status and Perspectives in the 21st Century. European Peregrine Falcon Working Group and Society for the Protection of Wild Animals "Falcon," Warsaw, Poland.

Siverio, M., and D. Concepción (2004). Halcón tagarote Falco pelegrinoides pelegrinoides. In Libro Rojo de Las Aves de España (A. Madroño, C. González and J. C. Atienza, Editors). Ministerio de Medio Ambiente-SEO/BirdLife, Madrid, Spain. pp. 171-173.

Siverio, M., B. Rodríguez, and F. Siverio (2009). El halcón tagarote en Canarias. In El Halcón Peregrino en España: Población Reproductora en 2008 y Método de Censo (J. C. del Moral, Editor). SEO/BirdLife, Madrid, Spain. pp. 52-58.

Siverio, M., F. Siverio, B. Rodríguez, and A. Rodríguez (2011). Long-term monitoring of an insular population of Barbary Falcon Falco peregrinus pelegrinoides. Ostrich 82:225-230.

Soutullo, A., L. Cadahía, V. Urios, M. Ferrer, and J. J. Negro (2007). Accuracy of lightweight satellite telemetry: a case study in the Iberian Peninsula. Journal of Wildlife Management 71:1010-1015. 
Stabile, F. A., G. J. Watkins-Colwell, J. A. Moore, M. Vecchione, and H. Burtt (2016). Observations of passerines and a falcon from a research vessel in the western North Atlantic Ocean. Wilson Journal of Ornithology 129:349-353.

Thorup, K., T. Alerstam, M. Hake, and N. Kjellen (2003). Bird orientation: compensation for wind drift in migrating raptors is age dependent. Proceedings of the Royal Society of London B 270:8-11.

White, C. M., T. J. Cade, and J. H. Enderson (2013). Peregrine Falcons of the World. Lynx Edicions, Barcelona, Spain.

Whittington, B. (2014). Peregrine Falcon hunting from cruise ships. British Columbia Birds 24:6-8.

Wiens, J. D., B. R. Noon, and R. T. Reynolds (2006). Postfledging survival of Northern Goshawks: the impor- tance of prey abundance, weather, and dispersal. Ecological Applications 16:406-418.

Yamaç, E., and C. Bilgin (2012). Post-fledging movements of Cinereous Vultures Aegypius monachus in Turkey revealed by GPS telemetry. Ardea 100:149-156.

Zuberogoitia, I., J. A. Martínez, A. Azkona, J. E. Martínez, I. Castillo, and J. Zabala (2009). Using recruitment age, territorial fidelity and dispersal as decisive tools in the conservation and management of Peregrine Falcon (Falco peregrinus) populations: the case of a healthy population in Northern Spain. Journal of Ornithology 150:95-101.

Received 23 January 2018; accepted 12 June 2018 Associate Editor: Christopher J. Farmer 